\title{
海水浴場における避難訓練を対象とした継続的 実践研究
}

\author{
小池 則満 1 -中村 栄治 2 -服部 亜由未 3 - 森田 匡俊 4 - 正木 和明 5 \\ 1正会員 愛知工業大学教授 工学部土木工学科（† 470-0392 愛知県豊田市八草町八千草1247） \\ E-mail: koike123@aitech.ac.jp \\ 2正会員 愛知工業大学教授 情報科学部情報科学科（一 $470-0392$ 愛知県豊田市八草町八千草1247） \\ E-mail: eiji-nakamura@aitech.ac.jp \\ 3非会員 愛知県立大学准教授 日本文化学部歴史文化学科（†480-1198愛知県長久手市茨厅迴間1522-3） \\ E-mail: ayumi-h@jps.aichi-pu.ac.jp \\ 4非会員 岐阜聖徳学園大学専任講師 教育学部（干501-6194 岐阜県岐阜市柳津町高桑西一丁目一番地） \\ E-mail:mmorita@gifu.shotoku.ac.jp

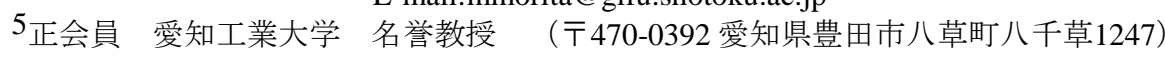 \\ E-mail: masaki@aitech.ac.jp
}

\begin{abstract}
海水浴場など, 他地域から多くの人が訪れる観光地では, 来訪者が周辺の地理情報に疎く, 避難場所, 避難経路などの情報の周知も難しいと考えられる，そのため，沿岸部の観光地には，観光客を守るための 適切な避難誘導を行える力も持つことが求められる。そこで本研究では地元住民によって企画される避難 訓練が，どのように実施され改善が重ねられたか，観察と参加者へのアンケート調査の結果から検証した。 当初, 考えられていた避難場所が経路, 受入容量に問題があること, 距離があって来訪者から不満がでる と思われた避難場所でも大きな問題なく避難出来ることなどが確認され, 実践を通じた問題発見と解決策 を見い出すことができた。
\end{abstract}

Key Words : tsunami evacuation drill, beach, practical study

\section{1. はじめに}

海水浴場など，他地域から多くの人が訪れる観光地で は，来訪者が周辺の地理情報に疎く，避難場所，避難経 路などの情報の周知も難しいと考えられる．また，多く の観光客が海辺に滞在する際に津波警報等が発表された 場合, 避難場所への誘導が重要となる. そのため, 沿岸 部の観光地には，観光客を守るための適切な避難誘導を 行える力を持つことも求められる.

今までにも沿岸部の観光地に求められる対応について 様々な指摘がなされている. 特に, 海水浴場に限っても いくつかの先行研究がある.

先駆的な研究としては，杉本らは 2006 年から 2010 年 にかけて計 5 力所の海水浴場で行ったアンケート調査の 結果をまとめ，地元住民を主体とした防災対策から来訪 者を対象とした対策へ方向性を変えていく必要性を述べ ている ${ }^{1)}$ 。吉田らは，海水浴客は荷物をまとめる，車 へ一度戻るなどの行動をとることを指摘し，迅速な避難 についての周知徹底が重要であると述べている 2)。安
田らは津波避難に対するサーファーの意識について全国 調査を行い，津波そのものへの知識や避難に対する意識 が必ずしも高いと言えないことから，津波防災教育の必 要性を課題として述べている3).

避難訓練についての論文としては，照本は 2013 年に 行われた観光客を対象とした津波避難訓練について分析 し, 情報伝達, 避難誘導, 避難経路, 避難場所について 来訪者へ分かりやすく表示することが重要であると述べ ている ${ }^{4)}$ 。森田らは GPS ロガーによって避難訓練時の 行動分析を行っている. アンケート調査を併用すること で，初動の遅さや，避難経路の物理的キャパシティにつ いての考察を行っている5）。島田らは海水浴場での避 難訓練で得られたデータを援用してシミュレーションモ デルを構築し, 避難成功率の推計結果から避難誘導標識 の重要性について指摘している ${ }^{6)}$.

以上の通り, 海水浴場における避難に関する先行研究 は存在し, 課題の抽出等がなされている.しかしながら, 調査や避難訓練を通じて見い出された問題解決に向けて 地域が継続的に取り組んでいる活動内容を追跡調査し, 
その変化についてまとめた研究は見当たらない，地域防 災力を高めていくためには，繰り返し検証と改善を重ね てよりよいものを目指していくプロセスが重要であり， これを複数年かけて調査することは，同様の地域に対し て重要な示唆を与え得るものと考える.

そこで本研究は，地元住民によって企画される避難訓 練が，どのように実施され改善が重ねられたか，主催者 への参与と参加者へのアンケート調査の結果から検証す る.これによって海水浴場という特徵的な観光地におけ る津波対策について地域が取り組む際の要点や課題につ いて論じることを目的とする.

\section{2. 対象地域および訓練の概要}

\section{(1) 対象地域}

対象地域は愛知県南知多町にある内海海水浴場とする 南知多町は愛知県の知多半島南部に位置する人口約 19000 人，面積 $38.37 \mathrm{~km}^{2}$ の町である. 名古屋から鉄道で 約 1 時間とアクセスがよいことから，観光地として賑わ っている. 内海海水浴場が立地する内海地区には自主防 災組織としての内海山海防災連絡協議会や，内海・山海

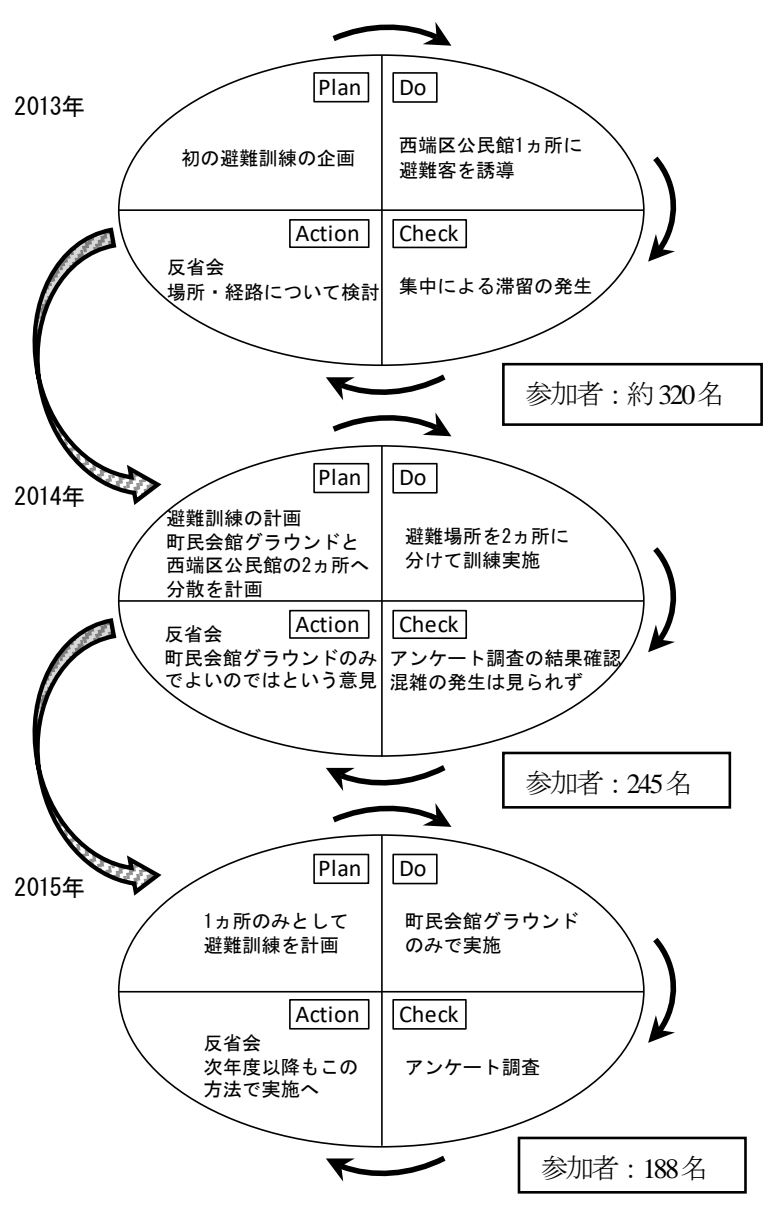

図-1＼cjkstart調査対象避難訓練のPDCAサイクル
まちづくり協議会（通称 : きずなの会）防災部会などが あり，活発に地域防災力の向上に取り組んでいる.内海 海水浴場は，南海トラフ巨大地震の発災時には $4.9 \mathrm{~m}$ の 津波が 30 分ほどで到達すると想定されている.

そこで 2013 年 7 月 15 日，内海海水浴場にて初の津波 避難訓練がきずなの会のメンバーらによって企画され実 施された.この時には近くにある西端区公民館に海水浴 客をはじめとする避難者全員（約 320 名参加）を誘導し たが，多数の避難者による滞留などが見られたことから 場所と経路を再検討することとなった．この訓練の内容 については前述の森田らの研究に詳しい.

この訓練企画時より，きずなの会防災部会の月例会議 に筆者らも参加するようになり，特に毎年の海水浴場訓 練については，企画段階から参与してきた。地元で開か れる訓練報告会にて調査結果を地元住民へ説明し，次年 以降の参考となるよう努めてきた. その結果, 図-1 に 示すような PDCA サイクルに沿う形で，Plan（計画） $\rightarrow$ Do (訓練実施) $\rightarrow$ Check（調査結果の検証） $\rightarrow$ Action （反省会にて改善策の検討と実施）が繰り返されてきた. 以下に，森田らの研究以降となる 2014 年と 2015 年の避 難訓練に関わる概要について，特に避難場所の変遷を中 心に記述する.

\section{(2) 2014年訓練の概要}

2013年の避難者の集中による滞留の発生への反省を受 けて，2014年の避難訓練が企画された．多数の観光客が スムーズに高台まで避難するには場所の分散を図ること が不可欠と考えられたことから，図-2に示すように海水 浴場より西側に位置する町民会館グラウンドへも避難誘 導することが計画された。 この時，懸念されたのが避難 場所までの距離である. 図中に本部と記されている付近 が内海海水浴場で最も観光客で賑わっている浜辺である ため，西端区公民館よりも遠くなってしまう。また，国

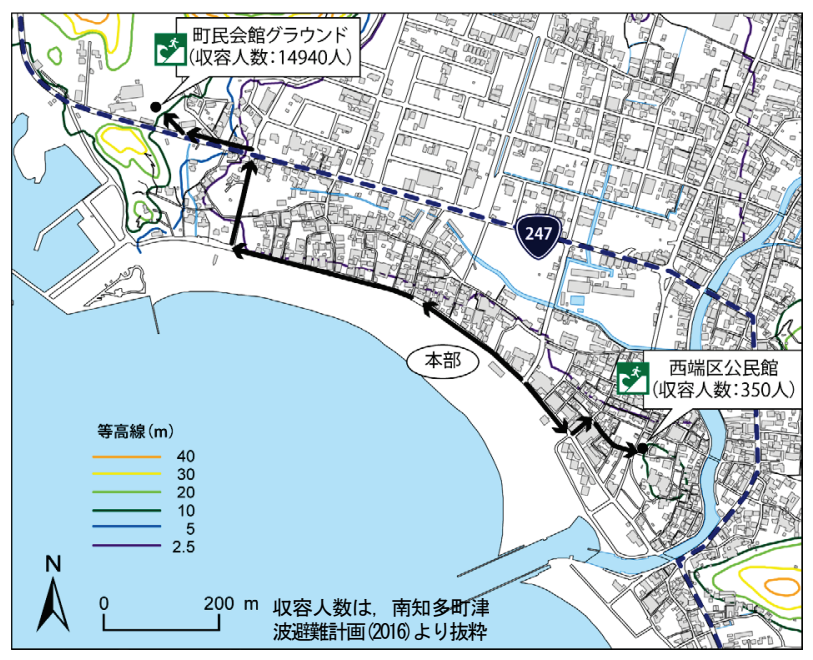

図-2 避難経路の変遷 
道の横断も発生するため, 津波到達までに全員が避難を 終えることができるかどうか懸念された。しかしながら， 図中に示したとおり，西端区公民館は収容可能人数が非 常に少なく7), 多数の観光客を収容する場所としては, 町民会館グラウンドを使用せざるを得ないと考えられた。

そこで避難場所までの移動を観光客がじのように捉え たのかを中心にアンケート調査を行うこととした.

調査実施日は2014年7月21日（月）であり，祝日（海 の日）だったため朝から多くの観光客で賑わっていた. 午前 9 時15分から随時, 海水浴場観光客に向け避難訓練 の予告, 参加者の募集を行い, 午前9時30分から避難訓 練参加者の受付を行った. 訓練開始時点の午前10時30分 に海水浴場に設置されている放送設備を使用し，地震発 生の放送を行った. その3分後の午前10時33分に大津波 警報発表のアナウンス放送が入ると同時に避難誘導を開 始した．避難経路上には避難訓練スタッフ及ひ警察官を 配置し, 参加者への誘導, 安全確認を行っていた. 避難 開始数分後から避難場所に到着する参加者が現れ, 到着 した順にアンケートの実施，参加賞の配布を行った．午 前10時50分ごろ西端区公民館への避難が完了し，午前11 時ごろ町民会館グラウンドへの避難を完了した． 午前12 時, 避難訓練スタッフは本部に移動し全体反省会後避難 訓練は終了した.

当日の参加者は公式発表ではスタッフ含め 475 名が参 加し, 避難訓練の一般参加者は 245 名であった. スタッ フ(230 名) は消防団や役場職員、誘導のボランティア、 中学生スタッフなどである. なお，中学生スタッフは避 難訓練の呼びかけやシナリオに基づいたアナウンスを担 当している.

参加者へのアンケートの調査結果は 2014 年 9 月 7 日 に開かれた報告会にて筆者らよりきずなの会メンバーを はじめとする地域住民に報告された。アアンート結果に ついては次章にて詳述する.

\section{(3) 2015年訓練の概要}

2014 年に行われた避難訓練において，町民会館グラ ウンドの広さについて良好な評価を得たことや避難時間 も想定される津波到達時間よりも早かったことから， 2015 年は避難先を町民会館グラウンド一箇所に絞って 行われた。

実施日は 2015年 7月 20 日（月）の祝日（海の日）で あり，天候は晴天であった。前年同様に午前 10 時 30 分 に大地震が発生したと放送を行った. 午前 10 時 33 分に 先に起こった大地震から，大津波警報が発表されたとい う放送を行い，午前 10 時 34 分に地域のスタッフが避難 誘導を開始した。 2014 年同様, 避難経路ではスタッフ が旗やハンドマイクを利用し参加者を誘導した．町民会 館グラウンドでは避難してきた参加者へのアンケートが
順次行われた. 約 22 分で参加者全員の避難が完了した. 放送設備については，海岸のみでなく地域全体に聞こえ る同報無線を利用した．当日の参加者は公式発表ではス タッフ含め 414 名が参加し, 避難訓練の一般参加者は 188 名であった。 スタッフ(226 名)は、昨年同様に消防 団や役場職員、誘導のボランティア、中学生スタッフな どであり, 2014年度と同様である.

2015 年 9 月 25 日に報告会が実施された。ここでアン ケート結果が筆者らから示され, 多くの避難訓練参加者 から町民会館グラウンドへの避難について支持が得られ ていると判断した. 南海トラフ地震の津波到達想定時間 の約 30 分よりも早く避難完了できていることから, 次 年以降もこの形で行うことがきずなの会をはじめとする 参加者で確認された.

\section{3. アンケート調査の方法}

\section{（1）タブレット端末使用による調査概要}

本研究のアンケート調査では, 海水浴場での調査とい う特殊性を考慮し，タブレット端末による調査を実施す ることとした. これは, 多くの参加者は海から水着等で 上がっており筆記具等の使用には抵抗感があると思われ ること，テーブル等の筆記台を用意し順に回答を受け付 けると時間とスペースが要ること, 真夏の野外調査で熱 中症が危惧されることから, 可能な限り短時間で回答作 業を終了したいことが理由である. 写真-1 に示すよう に, 避難してきた参加者に対して調査員が声かけをし, 質問をしながら回答を入力した.

2014 年と 2015 年のアンケート調查において使用した タブレット端末は, 共に Google 社の Nexus7 である.こ の端末の OS は Android5.0であり，ID タグを読み取るこ とができる NFC デバイスが実装されている. アンケー トの質問と回答の選択肢がタブレット端末に表示される ようアプリを作成した。 アプリは質問者がアイコンをタ

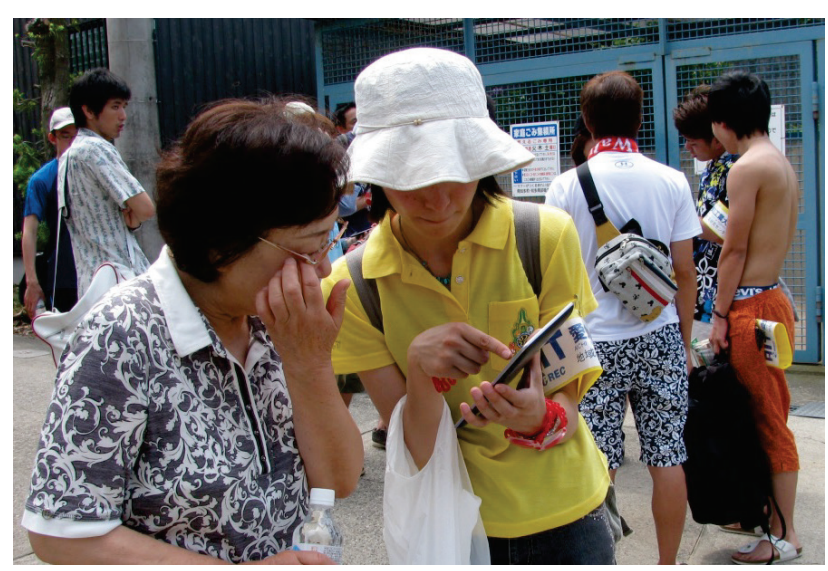

写真-1 タブレット端末による野外でのアンケート調査の様子 
ップするか（2014 年と 2015 年），避難訓練参加者が身 に付けている ID タグをタブレット端末に近づけること で自動的に起動できるようにした（2014 年）。質問と 回答選択肢の表示例を図-3 に示寸．アンケート調查の まとめ作業を考慮して，選択された回答をタブレット端 末内のローカルフォルダに CSV ファイルとして保存し, タブレット端末から CSVファイルを PCへダウンロード できるようにした.

\section{（2） 2014年のタブレット端末使用による調査}

まず訓練受付時，参加者にリストバンド型 ID タグを 配布し, 属性（性別, 年齢, 居住地) の調査を行った.

次に，避難終了後に ID タグをタブレット端末で読み 取ってからアンケート調查と録音を行った．受付時と同 じ ID タグを読み込むことで属性データと訓練終了後の データと結合することができる，なお自由意見聴取のた めの録音はアンケート開始直後に自動で始まり，終了ボ タンを押すのと同時にタブレット端末内に保存されるよ うにした。

このように受付時と訓練終了時の 2 回に分けてアンケ 一トを行ったのは, アンケート調査を行うことによる避 難場所での混雑を少しでも緩和するため，および訓練参 加者の避難場所での質問時間を短くし，熱中症等の発生 を防ぐためである．なお，受付を行わなかった参加者に ついては, 避難場所で属性入力から行えるようにした. 用意したタブレット端末は21台であった.

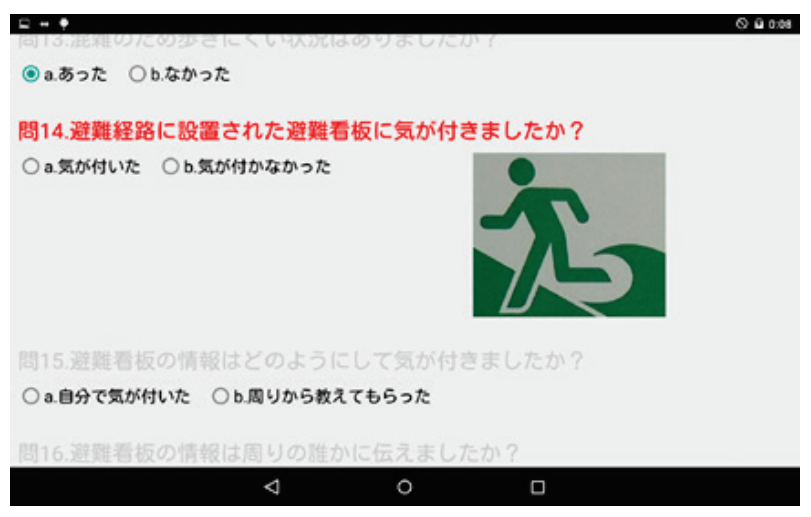

図-3タブレットの質問と回答画面の例

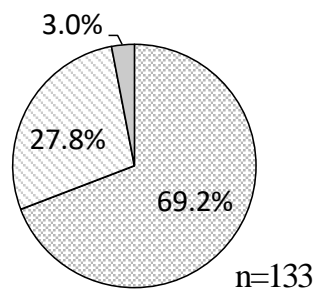

口男口女 口不明

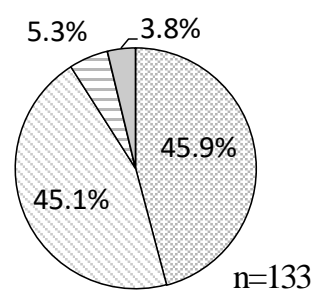

$\square$ 南知多町内 $\square$ 愛知県内 $\square$ 愛知県外 $\square$ 不明
図-4 参加者の性別(2014 年) 図-5 参加者の居住地(2014 年)

\section{（3） 2015 年のタブレット端末使用による調査}

基本的には 2014 年と同様の方法で，タブレット端末 による調査を行ったが，前年行った受付での ID タグ配 布は行わないこととした. 理由としては，受付をしない 参加者への対応に調査員が手間取ったこと，属性入力も 避難場所で行ってもそれほど時間がかからないと判断し たこと，などである.

\section{4. 調査結果}

\section{（1） 2014年における避難場所についての集計結果}

アンケートの回答者は 133 名であり，避難者 245 名よ りアンケートの回収率は 54.3\%であった。回答者属性を 図-4〜6 に示す. 性別については男性の比率が 7 割と高 くなっている. 居住地については, 地元である南知多町 内の方が 45.9\%と多かったが，愛知県内からの参加者も 45.1\%であった. 愛知県外からの参加者 5.3\%とあわせて 半数の参加者が町外からの来訪者であり, 土地勘はない ものと考えらえる. 年齢についても中学生以上と 30 代 をあわせて 50\%を超えており，若年層の参加が多かった ことがわかる。

図-7に避難場所別の「避難場所までの移動途中，道 の幅は狭いなど歩きにくい場所はありましたか」の問い についてのクロス集計結果を示す．町民会館グラウンド へ避難した方のうち，歩きにくい場所があったと回答し

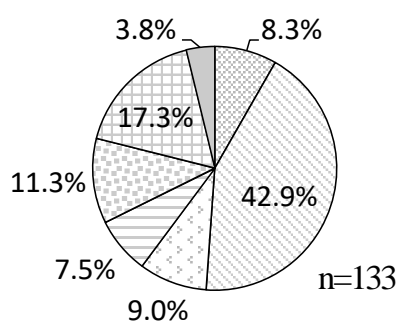

$\square$ 小学生以下 $\square$ 中学生以上 $\square 30$ 代

$\square 40$ 代 $\square 50$ 代 $\square 60$ 代以上

口不明

図-6＼cjkstart参加者の年齢(2014 年)

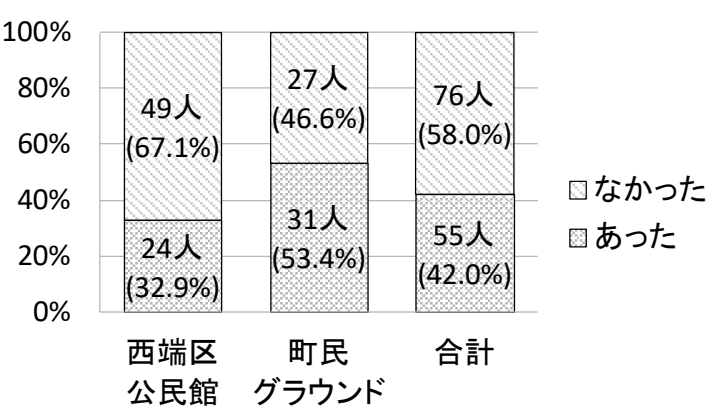

図-7避難場所別の歩きにくい場所の有無についての クロス集計結果 
た方が 58 人中 31 人と $50 \%$ 超える結果であつた. 西端 区公民館の場合，歩きにくい場所はなかったと回答した 方が 73 人中 49 人と $60 \%$ を超える結果であった. しかし 歩きにくい場所があったと回答した方の中に，「人混み のせいで狭く歩きづらい」との自由意見があり，混雑で 歩きにくいと感じた方も多かったと考えられる.

図-8に避難場所別の避難場所までの距離は遠いと感 じたかのクロス集計結果を示す．全体的に感じなかった 方が多いが，町民会館グラウンドへ避難した参加者の方 が距離が遠いと感じたという傾向にあるといえる.

図-9に「途中、避難看板に気が付きましたか」の問 いに対するクロス集計結果を示す．西端区公民館へ避難 した参加者の方が気付いた割合が低くなっている.

図-10 に避難場所の広さについてのクロス集計結果を 示す．西端区公民館へと避難した方の約 70\%の方が狭い と感じており，町民会館グラウンドでは 70\%を超える方 が広いと感じている結果であった. 録音による自由意見

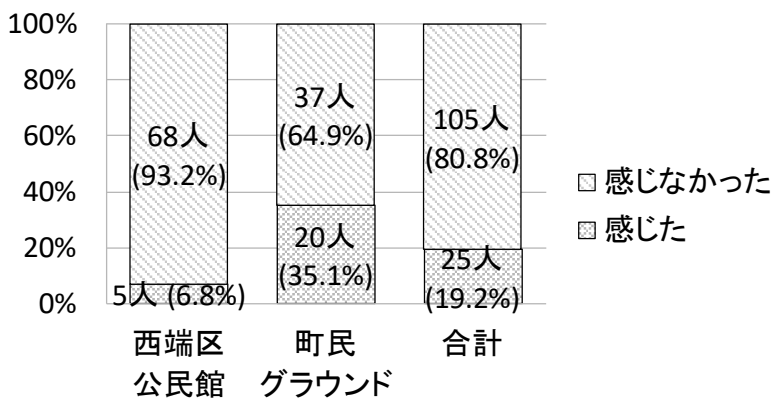

図-8 避難場所別の避難場所までの距離は遠いと感じたかの クロス集計結果

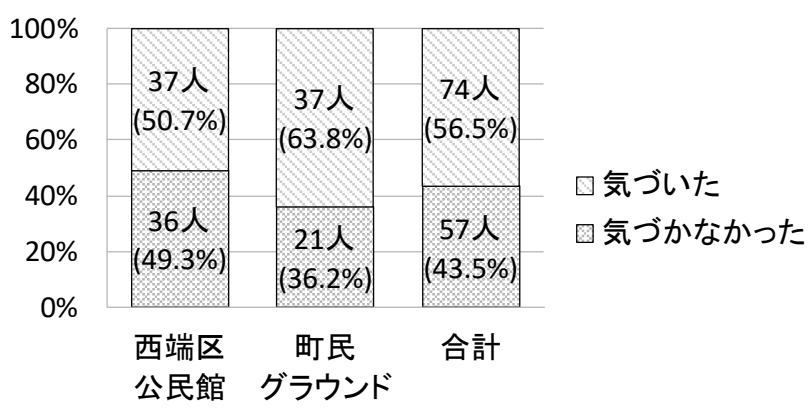

図-9 避難場所別の看板に気づいたかどうかのクロス集計結果

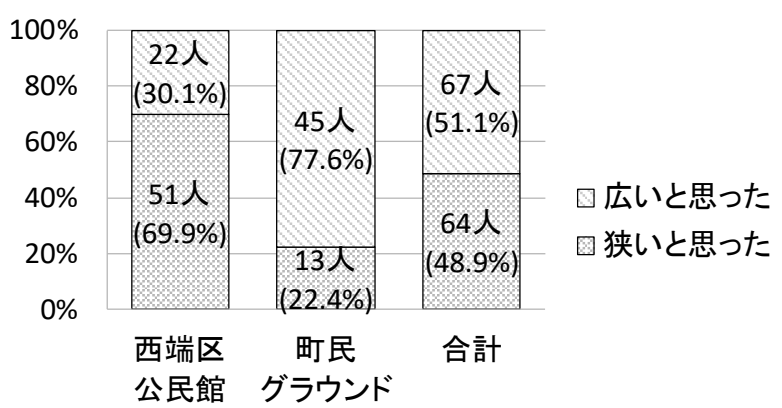

図-10 避難場所別の避難場所の広さについての クロス集計結果
において，「人が多いがために狭いのでは」との意見が あつた。

(2) 2015年におけるアンケート集計

アンケートの回答者は 128 名であり，避難者 188 名よ り，アンケートの回収率は 68\%であった．回答者属性を 図-11〜13 に示す. 性別については男性の比率が 2014年 度同様に高くなっている，居住地については，南知多町 内の方が約 4割であるが，町外からの来訪者である愛知 県内および県外からの参加者が約 6 割となっている. 年 龄については項目を簡素化してアンケートをとったため 2014 年度との比較は難しいが，60 代以上の参加は 1 割 程度であり，若年層の参加が多かったことがわかる。

図-14 は「避難している際の案内や誘導は分かりやす かったですか?」の問いに対する集計結果である．全体 の 88\%（113 人）が，避難誘導は分かりやすかったと回 答した.

図-15 は「混雑のため歩きにくい状況はありました か?」という問いの集計結果である. 昨年のアンケート

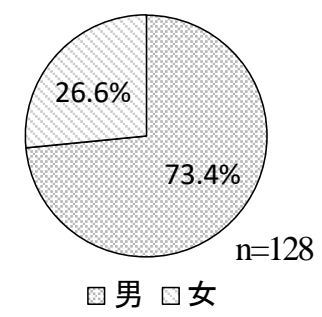

図-11 参加者の性別(2015 年)

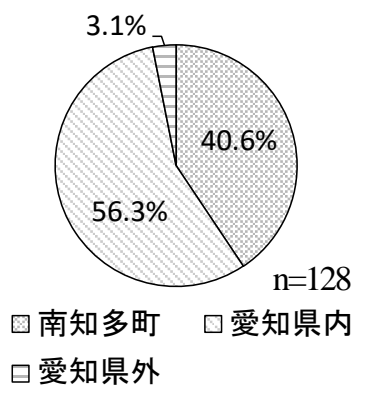

図-12 参加者の居住地(2015 年)
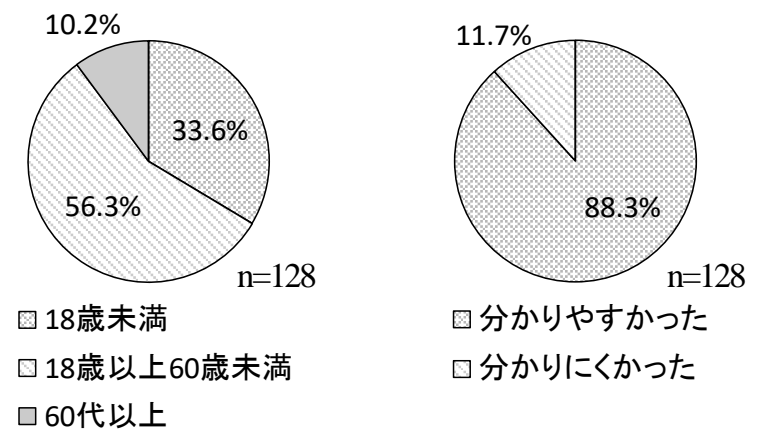

ロ分かりやすかった

ロ分かりにくかった

図-13参加者の年齢(2015 年)
図-14 避難誘導について 


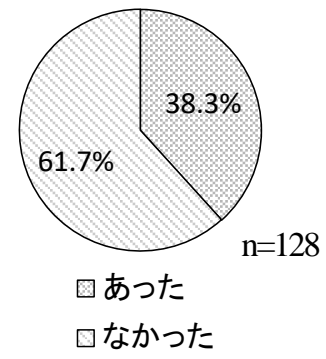

図-15 混雑による歩きにくさについて

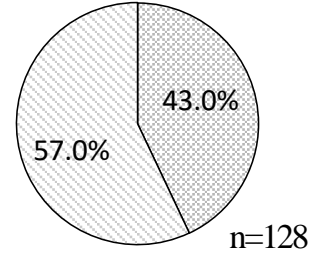

$\square$ 感じた

感じなかった

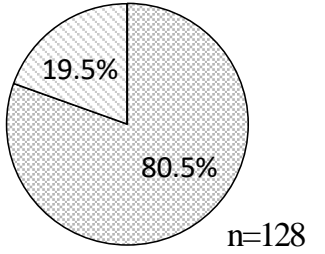

口広いと思った

口狭いと思った
図-16 距離について

図-17避難場所について

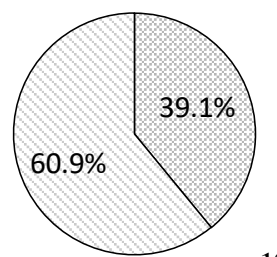

ロ気が付いた $\mathrm{n}=128$

ロ気が付かなかった

図-18避難経路に設置された避難看板について

結果において，“歩きにくい”という問いに対する理由 が不明であったため，2015 年には設問中に“混雑のた め”という文節を追加している．全体の 61.7\%（79人） が歩きにくい場所はなかったと答えている．設問文が異 なるため単純な比較は難しいが，前年の結果（図-7）よ りは改善されている.

図-16 は避難場所までの距離についての集計結果であ る. 57\%の方が避難場所を遠いと感じなかったと回答し た. 2014 年は, 町民会館グラウンドに避難した参加者 の 60\%以上が距離を遠いと感じなかったと回答しており， 「遠い」という印象が増加している.

図-17 は避難場所の広さについての集計結果である. 80\%の方が避難場所は広いと回答しており，2014 年より も良い印象となっている.

図-18に避難看板に気付いたかどうかの回答結果を示 す. 図-9 と比較して，「気が付いた」という割合が下 がっている.

図-19 に「津波避難訓練のための放送は聞き取りやす かったですか?」と「避難を開始するとき、どこに向か って移動すればいいかすぐにわかりましたか?」につい てのクロス集計結果を示す，避難放送が聞き取りやすか

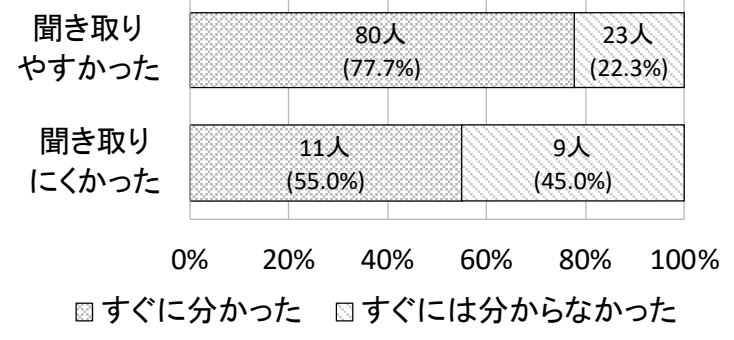

図-19 避難放送と避難方向についてのクロス集計結果

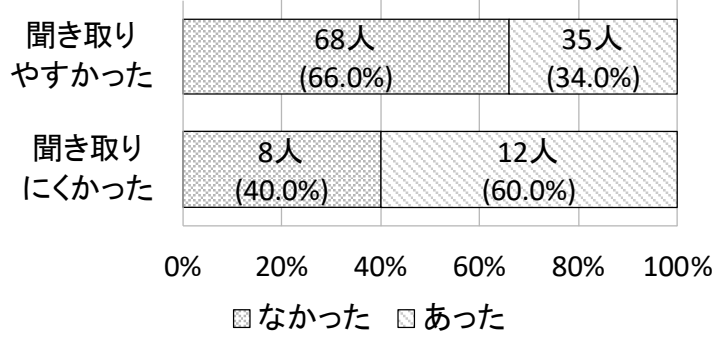

図-20 避難放送の聞き取りやすさと混雑の有無についての クロス集計結果

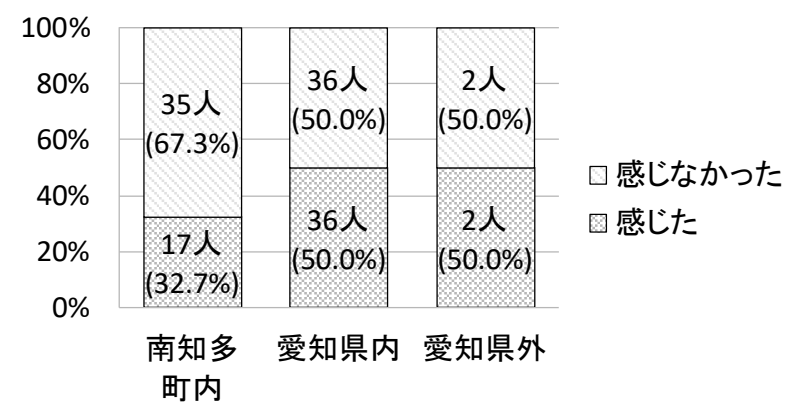

図-21 居住地と距離についてのクロス集計結果

つた方は避難方向もすぐに認識できたといえる，カイ二 乗検定の結果，有意差がみられた（ $\chi^{2}=4.472, \mathrm{p}<0.05 ）$.

図-20に避難放送と混雑の有無についてのクロス集計 結果を示す。放送が聞き取りにくかったと答えた人ほど 混雑があったと回答した割合が高い. カイ二乗検定の結 果，有意差がみられた（ $\chi^{2}=4.472, \mathrm{p}<0.05 ）$.

図-21 に居住地と避難場所までの距離が遠いと感じた かのクロス集計結果を示す. 統計的な有意差はみられな かったが，南知多町内にお住まいの参加者のほうが遠い と感じていない割合が高く，町外からの参加者では，遠 いと感じた参加者とそうでない参加者が半々の割合にな っていることがわかる.

\section{5. 考察}

\section{(1) 避難場所の改善}

歩きにくい場所（図-7と図-15）の回答結果について， 町民会館グラウンドへ避難した方で比較しても改善され 
ている. 避難場所の広さ（図-10と図-17）についても, 同じ町民会館グラウンドへ避難した方と比較しても，改 善されている. 設問文に若干の相違はあるが，全体とし て良い方への意見が多くなっている，遠く感じたという 割合は増加しているがそれでも全体の半数以上は遠いと は感じなかったと回答している. これらの結果を踏まえ て2016年以降は町民会館グラウンドに避難場所を固定し, 別の課題についての改善に取り組むこととなった.

このように, 問題点を明確にし, 分かりやすい施策と 検証を行ったうえで，毎年の避難訓練を行うことは，速 やかな避難の実現に向けて非常に有効であるといえる.

なお，避難訓練への一般参加者が年々減少傾向にあり， それにより相対的に評価が良くなっている可能性もある. しかしながら，2014年には2力所に分散されていた避難 場所が2015年には1力所にまとめられて, 参加者全員が 町民グランドに避難をしていることから，単純に考えれ ば避難経路での混雑は増したと考えられる。したがって 参加者全体の減少が混雑を緩和して良い評価につながっ たとは考えられず，避難経路の物理的な条件や避難誘導 など, 複数の要因が重なっているものと考えられる.

遠いと感じた参加者（図-8と図-16）も増加している. 訓練での津波到達想定時間よりも早く避難場所に集まっ ているとはいえ，遠いとの評価は望ましいとはいえない. 図-21に示すとおり, 南知多町内からの参加者の方が遠 いと感じた割合が低いことから，事前に場所を知ってい るかどうかで感じ方が変わってくる可能性がある.今回 の調査では統計的な有意差はみられなかったが，検討課 題であるといえる.

いずれにしても, 今回の参加者属性や参加人数と評価 をひとつの基準として同様の避難訓練に対する計画や検 証に用いれば，相対的な優劣が判断でき，その後の対策 を考えるうえでの参考になるといえる.

\section{(2) 誘導の重要性}

2014年の訓練における自由意見にあった通り，避難場 所の広さや歩きやすさに対する印象は避難人数との相対 的な評価と考えられる点に注意する必要がある.すなわ ち，できるだけ滞留のないように順序よく誘導していけ ば，広さや歩きやすさといったハードに対する不満要素 も軽減できると考えられる．2015年の訓練結果において， 図-19および図-20に示した通り，放送が聞き取りやすか ったと印象の参加者ほど，避難方向の認識も良好で，歩 きにくさも感じていない.すなわち放送が聞き取れ，初 動が早かった参加者ほどスムーズに行動できたものと推 察される.

一方で，避難看板については，多数の看板が2015年に おいても設置されたが，2014年と比較しても，評価はあ まり変わらなかった，避難看板の設置方法等に問題があ
るのか，それとも避難看板そのものが大人数で避難する 海水浴場ではあまり有効ではないのか, 今後, 検討する 必要がある。

\section{6. まとめと今後に向けて}

本研究では，海水浴場で行われる津波避難訓練に対し て複数年にわたって参与および調査し, その改善過程に ついて取りまとめた．特に避難場所の設定について，参 加者へのアンケート調査によって避難経路や避難場所の 広さなどについての意見を伺った上で，次年度の方針を 意思決定する PDCA サイクルを回した. 何を改善する のか，を明確にして対策を施して検証を重なることが訓 練を継続的に行う意義を深めるポイントであると実践を 通じて示すことができた.

今後も継続して訓練について課題を設定したうえで見 直していくことが重要であるが，それに応じて調査方法 についても工夫が必要となってくる. 今回はタブレット 端末によるアンケート調査で炎天下での調査にトラブル なく対応することができた，今後は，たとえば安否確認 システムへの発展も視野にいれた調査システムを構築し ていくことも一つのアイディアであろう.

謝辞 : 本稿をまとめるにあたり，内海山海防災連絡協議 会, 内海・山海まちづくり協議会防災部会の皆様に大変 なご協力をいただいた，また，調査結果とりまとめの一 部において JSPS 科研費 16 K02089 からの助成を受けた. 記して御礼申し上げる.

\section{参考文献}

1) 杉本晃洋, 大年邦雄, 石垣泰輔, 島田広昭 : 海水浴場利 用者の津波防災意識に及ぼす防災教育や対策の効果，土 木学会論文集 B3（海洋開発），Vol.67，No.2，I_547-552， 2011.

2) 吉田太一, 梅本通孝, 系井川栄一, 太田尚孝 : 海水浴客 の津波避難行動特性に関する研究—大洗サンビーチ海水 浴場を対象として一 地域安全学会論文集 No.21, pp.149158, 2013.

3) 安田誠宏, 畑山満則, 島田広昭: 津波避難に対するサ一 ファーの意識の全国調査, 社会安全学研究, 第 6 号, pp.61-80, 2016.

4) 照本清峰: 観光地における津波避難体制の課題とあり方 に関する一考察, 都市計画論文集, Vol.48, No.3, pp.795800, 2013.

5) 森田匡俊, 小池則満, 小林哲郎, 山本義幸, 中村栄治, 正木和明 : GPS を用いた海水浴場避難訓練時の行動分析 一愛知県南知多町を事例として一 地域安全学会論文集 
No.23, 2014.

6) 島田広昭，川中龍児，石垣泰輔，大年邦雄，武藤裕則，

馬場康之 : 避難訓練データを援用したマルチエージェン

トモデルによる海水浴場利用者の安全避難に関する検討,
土木学会論文集 B2（海岸工学），Vol.70，No.2，I_1346-

1350, 2014.

7) 南知多町 : 南知多町津波避難計画, 2015 .

(2017.7.7 受付)

\section{CONTINUOUS PRACTICAL STUDY ABOUT TSUNAMI EVACUATION DRILL AT A BEACH}

\section{Norimitsu KOIKE, Eiji NAKAMURA, Ayumi HATTORI, Masatoshi MORITA and Kazuaki MASAKI}

It is especially difficult to inform visitors who are not acquainted with the risks of the places near the water under a tsunami attack regarding evacuation routes and shelters. Resorts near the water must have the ability to keep visitors safe in a tsunami attack. Through participation observation during evacuation drills at Utsumi Beach, Aichi, Japan, we discuss how to smoothly evacuate visitors and residents from the beach to the tsunami shelter. The visitor's awareness of the risk was addressed through a questionnaire survey using a tablet type computer. Some improvements must be made in the process. As an example, the location of the tsunami shelter had to be changed. We point out the significance of conducting the evacuation drills on a continuous basis. 